\section{Dialogismo e espetacularização nas capas da Veja e tweets: o primeiro mês do governo Bolsonaro}

Anderson William Marzinhowsky BENAGLIA (UNIP) anderson.wbe@hotmail.com Barbara HELLER (UNIP) b.heller.sp@gmail.com

Recebido em: 30 de dez. de 2020. Aceito em: 08 de out. de 2021.

Dialogism and spetacularization on the covers of Veja and tweets: the first month of Bolsonaro government

Cristiane FURLAN (UNIP) cristianefurlan@hotmail.com

\title{
00000000000
} \section{.} in interpretativa, as imagens postadas no
Twitter no mesmo dia da publicação de Veja e as relações com os enunciados verbais que as acompanham. Para tanto, apoiamo-nos nos conceitos de dialogismo, vozes e discurso centrípeta, de Mikhail Bakhtin (1999, 2010, 2015), e de espetacularização, de Guy Debord (1997). Concluímos que enquanto a revista põe a público a descrença em seu governo, o Twitter, em uma relação dialógica, edifica sua imagem, mostrando-o como homem de ação.

Palavras-chave: Mídia. Dialogismo. Espetacularização. 
Abstract: This article seeks to understand the sense disputes attributed to the first thirty days of Bolsonaro government, in January 2019, on the covers of Veja magazine, one of the periodicals with the largest print run and circulation in Brazil, with approximately 556,000 weekly copies, and in the tweets from the president's personal account, the media with the largest number of followers and the one that he has used most since his campaign. We analyzed, through a qualitativeinterpretive approach, the images posted on Twitter on the same day as the Veja publication and the relations with the verbal statements that accompany them. To do so, we relied on the concepts of dialogism, voices, and centripetal discourse, by Mikhail Bakhtin (1999, 2010, 2015), and of spectacularization, by Guy Debord (1997). We concluded that while the magazine makes public the disbelief in his government, Twitter, in a dialogic relationship, builds his image, showing him as a man of action.

Key-words: Media. Dialogism. Spectacularization.

\section{Introdução}

As últimas eleições presidenciais no Brasil (2018) acirraram a polarização política que já vinha se configurando nacional e internacionalmente, com o avanço da extrema-direita em muitos países e de suas estratégias de pensamento único. Conforme aponta Braga, as sociedades encontram-se divididas "entre os que reforçam polarizações e os que são aí oprimidos" (2020, p. 3).

No Brasil, as crescentes disputas políticas e comportamentais giram entre os que defendem a ideologia com viés mais progressista, isto é, associada à esquerda, e os que se consideram mais conservadores, ligados ao pensamento da chamada direita. Independentemente da simpatia por determinados partidos em detrimento de outros, a ideia predominante, colocada em uso nas nossas práticas cotidianas, é considerar amigos apenas os que concordam com nossas ideias; os demais, são automaticamente nossos inimigos ${ }^{1}$.

Empiricamente, podemos afirmar que tal acirramento se intensificou quando Jair Messias Bolsonaro, ainda candidato, foi vítima de um atentado em comício para eleição presidencial em 06 de setembro de 2018, na cidade de Juiz de Fora, Minas Gerais. Desse momento em diante, sua campanha ganhou envergadura e muita polêmica. Seus correligionários suspeitaram de um atentado organizado

${ }^{1}$ Träsel, Lisboa e Vinciprova apontam a mesma característica comportamental dos grupos sociais ao afirmarem que estamos na era da pós-verdade, ou seja, quando notícias falsas, manipuladas, impostas e fabricadas ignoram os fatos e tomam emprestadas "as marcas discursivas de uma instituição social dos Estados democráticos para levar o leitor a conferir maior credibilidade a seu conteúdo" (2019, p. 481-482). 
V. 11 (3) $356-385$ set-dez 2021

pelos candidatos dos outros partidos, seus opositores, o que se mostrou infundado ${ }^{2}$.

Ainda que tais antecedentes não expliquem exclusivamente seu sucesso, o fato é que, a partir de $1^{0}$ de janeiro de 2019, Jair Messias Bolsonaro passou a ocupar a $38^{\circ}$ cadeira presidencial da República Federativa do Brasil, eleito por voto direto.

Em meio a todo esse cenário de polarização e de intolerância, interessa-nos analisar as representações verbo-visuais do atual Presidente da República nos primeiros trinta dias do governo nas capas da revista Veja, graças à sua expressiva tiragem: cerca de $556 \mathrm{mil}$ exemplares impressos e digitais por semana e, por isso, considerada "a maior revista do Brasil e a segunda maior no mundo" (VEJA MIDIA KIT, 2019). Apesar da extinção, inicialmente de títulos tradicionais da Editora Abril (responsável pela publicação da Veja), e desde início de 2021, de suas instalações e parque gráfico, consideramos que ela ainda ocupa lugar relevante para se pensar fenômenos da comunicação contemporânea. A digitalização de todos os números anteriores até a edição mais recente, com mensalidades que variam de $\mathrm{R} \$ 14,90$ a $\mathrm{R} \$ 32,90^{3}$, dependendo do pacote escolhido, democratizou seu acesso pelo consumidor interessado em entender as notícias da semana pensadas para uma leitura rápida, semanal e com visual atraente.

Outro argumento que valida a relevância em analisar Veja é a carência de resultados significativos após uma busca com as palavraschave "Eleição 2018"; "Bolsonaro"; "Veja" entre os anos 2015 a 2020 na Biblioteca Virtual de Teses e Dissertações (BDTD), nos Repositórios Institucionais em Ciências da Comunicação (Reposcom), em periódicos bem qualificados pela Capes, em anais de evento como Intercom e, finalmente, no sistema EBSCO. Localizamos apenas o artigo "Disputas discursivas, legitimação e desinformação: o caso Veja x Bolsonaro nas eleições brasileiras de 2018", de Raquel da Cunha Recuero, sustentado pela seguinte pergunta de análise "Como ocorreram as disputas discursivas das narrativas anti e pró Bolsonaro no caso da matéria da revista Veja no Twitter?"

\footnotetext{
${ }^{2}$ A agência Lupa, que realiza checagem de desinformação, concluiu que "De acordo com informações oficiais, o nome do homem que foi preso em flagrante por esfaquear Jair Bolsonaro é Adélio Bispo de Oliveira - não José Adélio. José Adélio Bispo de Oliveira, que aparece nas notícias analisadas, é de fato filiado ao PDT de Minas Gerais, mas não é o homem preso pela agressão a Bolsonaro. Trata-se apenas de um homem com nome muito parecido. Disponível em: https://piaui.folha.uol.com.br/lupa/2018/09/06/atentado-bolsonaro-tempo-real/. Acesso em: 01 jul. 2021.
}

3 Valores praticados em 01 jul. 2021. 
Em contraponto à revista, elegemos a conta de Jair Bolsonaro no Twitter, mídia por meio da qual veiculou sua campanha e por onde ainda se comunica intensivamente com seus 16,5 milhões de seguidores, embora argumente que sejam mais de 35 milhões $^{4}$. Sua conta no Twitter ocupa a liderança de acesso nas redes sociais.

A presença do Twitter também se justifica pelo sistemático ataque que o atual presidente costuma fazer ao jornalismo profissional, em uma clara tentativa de desqualificá-lo e desacreditá-lo, desde que tomou posse. Acrescente-se a isso a dependência das mídias tradicionais em relação às vendas de assinaturas e de outros modelos de negócios para se equilibrarem financeiramente, face à competição dos novos suportes digitais, muito mais baratos e acessíveis.

Temos, portanto, como corpus de análise duas mídias que se caracterizam por serem, a primeira, uma das mais tradicionais e lidas entre as revistas de tiragem semanal e, a segunda, a com maior número de seguidores, considerada uma das redes sociais mais influentes, em especial na última campanha presidencial em nosso país (FIGARO et al, 2020). Veja configura o que chamamos de "indústria cultural" 5 , por meio da qual se reproduzem notícias em larga escala, voltada a um público massivo. A segunda, a conta do presidente no Twitter, por ser interativa, permite analisar ações e reações das postagens. Analisadas de forma comparativa, ambas podem apontar os sentidos em circulação e em disputa sobre o presidente, logo após o início de seu mandato.

Sabemos que as mídias digitais atualizam as notícias permanentemente, "a partir de várias vozes, cujas extensões e conexões são imprevisíveis" (FIGARO et al, 2020, p. 4), mas em nossa análise elegemos exclusivamente as postagens publicadas nos mesmos dias em que a revista Veja chegou aos seus leitores ou assinantes, seja pelo suporte impresso, seja pelo digital. Menos do que investigar as diferenças de suas materialidades e suas implicações, interessou-nos analisar as aproximações e os distanciamentos entre os enunciados em circulação nessas duas plataformas.

Se Veja se caracteriza por ser autorreferenciada, graças ao seu sistema de produção e de edição, com seu corpo de profissionais contratados

\footnotetext{
4 Disponível em: https://twitter.com/jairbolsonaro/status/1232649214905212930. Acesso em: 17 nov. 2020.

${ }^{5}$ Indústria cultural é um conceito originalmente pensado pelos teóricos da Escola de Frankfurt na metade do século XX. Atualmente, como sugere John Thompson, ela compreende três características: transformação das instituições da mídia em interesses comerciais de grande escala; globalização da comunicação; desenvolvimento das formas de comunicação.
} 
V. 11 (3)

$356-385$

set-dez

2021

e seu parque gráfico, o Twitter é seu oposto, pois nele cabem todos os usuários que desejam interagir, sem custo de produção, independentemente da posição que ocupam dentro e fora das redes sociais.

Concordamos com Fígaro et al quando postula que, "com as práticas do online, o jornalismo não está mais preso ao tempo do relógio da indústria moderna, mas ao relógio do pulsar do coração, das batidas coligidas pelo fato a ser reportado" (2020, p. 9). Ainda assim, as diferenças implicadas pelo dinamismo das redes sociais não impedem que as notícias que veiculam sejam examinadas sob os mesmos critérios e rigor que as publicadas pela mídia impressa.

Desse modo, elegemos como perguntas: quais efeitos de sentido sobre a imagem de Jair Bolsonaro foram construídos a partir das capas da Veja, nos primeiros 30 dias após sua posse? Como sua conta no Twitter o caracteriza no mesmo intervalo de tempo e nas mesmas datas em que a revista é publicada? É possível reconhecer dialogismo entre essas duas mídias? A revista Veja e os tweets do presidente são mídias espetacularizadas, como formulou Guy Debord?

Para tanto, amparados por uma abordagem qualitativa e interpretativa, isto é, que trabalha com método indutivo para compreender pessoas e seus contextos sociais e culturais (Myers apud Josemin, 2001), identificamos as capas da revista Veja de 01 a 30 de janeiro de 2019 que retrataram o recém-eleito Bolsonaro e, nos mesmos dias em que foram publicadas, os tweets do presidente. Além disso, analisamos os discursos de tais capas e tweets para compreender os efeitos de sentidos atribuídos a partir do conceito de dialogismo de Mikhail Bakhtin. Por fim, investigamos em ambos suportes como se manifesta o fenômeno da espetacularização de Guy Debord, um dos conceitos fundamentais para compreender a mídia massiva, da qual Veja e Twitter fazem parte.

Assim, pretendemos investigar a relação de sentidos atribuídos a Jair Bolsonaro, já como chefe do Estado brasileiro, em Veja e no Twitter, nos primórdios de seu mandato. Por essa razão, acreditamos que o presente artigo pode funcionar como complemento ao de Raquel Recuero.

O artigo encontra-se dividido em três seções: na primeira, apontamos tanto os autores quanto os conceitos utilizados para análise; na segunda, aplicamos os conceitos teóricos no corpus; e, na última, refletimos sobre as convergências e as divergências entre os suportes midiáticos pesquisados. 


\section{Corpus e referencial teórico-metodológico}

Como corpus selecionamos três capas da Veja, sendo a primeira edição de 02 de janeiro de 2019 e, a última, de 16 de janeiro do mesmo ano. Esse período compreende o primeiro mês do mandato presidencial, mas levamos em consideração para seleção apenas as que fazem referência direta à imagem de Bolsonaro.

A análise parte dos estudos discursivos de Mikhail Bakhtin, com o intuito de compreender os efeitos de sentido associados à imagem de Bolsonaro nas capas da Veja e nos tweets produzidos pelo presidente nas mesmas datas.

Se antes do surgimento da comunicação em rede o paradigma comunicacional ocorria exclusivamente de "um para todos", como em Veja, depois de sua disseminação, no final dos anos 1980, convivemos com o paradigma de "todos para todos", exemplificado pelo Twitter nesse artigo.

Para Guy Debord, notícias e até mesmo relações interpessoais tornam-se reais se forem mediadas pelas imagens, uma vez que "[...] o mundo real se converte em simples imagens, estas simples imagens tornam-se seres reais" (19976, p. 19). Luís Mauro Sá Martino (2013) analisa que o autor francês não faz crítica à indústria do entretenimento, da qual Veja e Twitter fazem parte, mas à transformação de todas as coisas em imagem. Os leitores de Veja e os seguidores no Twitter da conta de Jair Bolsonaro são, portanto, consumidores conformes à lógica do capital, que reproduz mercadorias em larga escala e em alta velocidade. Assim, as capas da Veja e as postagens no Twitter permitem identificar, em diferentes suportes, como se dão o consumo e as construções de sentido por meio das imagens: primeiro "de um para todos", e depois "de todos para todos".

A comunicação contemporânea, sobretudo a virtual7, é fluida, caracterizada pelo descentramento do sujeito e pelo jogo de identidades que assume diante da integração com a sociedade. Para Santos (2016, p.

\footnotetext{
${ }^{6}$ Infelizmente, a ficha catalográfica não consta na versão digital que consultamos para o artigo. Para todos os efeitos, assumimos a data de 1997, ano da primeira edição da obra, como informa a "Nota Importante", p. 4. Ver: https://www.marxists.org/portugues/debord/1967/11/ sociedade.pdf

${ }^{7}$ Não nos cabe aqui discutir a variação dos termos para o que estamos nomeando por "mídia virtual". Para alguns autores, trata-se de cibercultura; para outros, de comunicação mediada por computadores. Também há os que a denominam por internet studies. Em nosso artigo, estabilizamos o termo "mídia virtual", exceto quando as referências bibliográficas consultadas a citam por outro nome.
} 
V. 11 (3)

$356-385$

set-dez

2021

4), a comunicação mediada pelo computador indica a "impossibilidade de pensar o emissor, a mensagem e o receptor como momentos estanques, coerentes com uma lógica linear da qual a comunicação seria tributária".

Para Debord (1997), essa circunstância é um cenário fértil para a lógica do espetáculo, no qual ele é "ao mesmo tempo parte da sociedade, a própria sociedade e seu instrumento de unificação" (grifos do autor). No entanto, "o espetáculo não é um conjunto de imagens, mas uma relação social entre pessoas, mediatizada por imagens". Assim, "o espetáculo constitui o modelo presente da vida socialmente dominante". (p. 14) [grifos nossos].

Nesse sentido, as mídias virtuais são espaços privilegiados nos quais os produtores de conteúdo independentes alcançam visibilidade e notoriedade, em parte, pelos esforços empenhados em representar determinados grupos, culturas, perspectivas ideológicas, sociais e até mesmo políticas. Ou, como teoriza novamente Santos (2016), "o ciberespaço ${ }^{8}$ pressupõe uma mistura entre sujeito e objeto, impensável no processo de comunicação interpessoal e de massa" (2016, p. 4).

Na primeira edição de Veja, seus fundadores, Victor e Roberto Civita, tinham como propósito diminuir as barreiras entre informação e público, como destacamos:

O Brasil não pode ser o velho arquipélago separado pela distância, o espaço geográfico, a ignorância, os preconceitos e os regionalismos: precisa de informação rápida e objetiva a fim de escolher rumos novos. Precisa saber o que está acontecendo nas fronteiras da ciência, da tecnologia e da arte no mundo inteiro. Precisa acompanhar o extraordinário desenvolvimento dos negócios, da educação, do esporte, da religião. Precisa, enfim, estar bem informado. E este é o objetivo de VEJA (EDIÇÃO 1, set. 1968, p. 21) [grifos nossos].

Alinhada aos moldes da norte-americana Time ${ }^{9}$, a revista Veja apresenta características atraentes, seja pela estética e layout, seja pelos tratamentos espetacularizados que reconhecemos nas capas aqui apresentadas. A formulação de mídia como espetáculo, de Guy Debord, pensada para os meios de comunicação de massa, reforça

\footnotetext{
${ }^{8}$ Embora saibamos que não há equivalência entre "ciberespaço" e "mídias virtuais", mantivemos a nomenclatura original da autora.

9 Segundo o Correio Brasiliense Acervo, Roberto Civita "estagiou durante um ano e meio na editora Time Inc, que controlava as revistas Time, Life e Sports Illustrated" Disponível em: https://www.correiobraziliense.com.br/app/noticia/brasil/2013/05/27/interna-brasil,368071/ familiares-e-amigos-se-despedem-nesta-manha-do-empresario-roberto-civita.shtml. Acesso em: 25 nov. 2020.
} 
nossa compreensão de que a revista Veja obedece à lógica da indústria cultural e está comprometida com uma visão de mundo muito própria e unilateral:

O espetáculo, considerado sob o aspecto restrito dos "meios de comunicação de massa" - sua manifestação superficial mais esmagadora - que aparentemente invade a sociedade como simples instrumentação, está longe da neutralidade [...]. A administração desta sociedade e todo contato entre os homens já não podem ser exercidos senão por intermédio deste poder de comunicação instantâneo, é por isso que tal "comunicação" é essencialmente unilateral [...] (1997, p. 2122) [grifos nossos].

Se, como reforça Debord, nos meios massivos ocorre a "comunicação essencialmente unilateral", "longe da neutralidade", como poderemos interpretar as imagens que comparecem em Veja, especialmente nas suas capas, e que funcionam com o primeiro contato visual entre o leitor e a revista? É possível ser "objetivo", "acompanhar o extraordinário" e "bem informar", alguns dos objetivos almejados pelos irmãos Civita? Em relação ao Twitter, como essa empresa opera seus conflitos de interesses e consensos para manter sua posição no mercado no regime capitalista?

\section{Análise e interpretação de resultados}

A primeira capa da revista Veja com a imagem de Jair Bolsonaro em destaque, após a data em que assumiu o cargo de Presidente da República, foi lançada em 02 de janeiro de 2019, sob o título "Almanaque Bolsonaro". Contudo, percebemos que a edição da revista foi concebida antes da investidura do militar ao cargo, conforme indica o subtítulo "Um manual para entender a cabeça e o estilo do presidente que toma posse em $1^{0}$ de janeiro de 2019" (Fig. 1) ${ }^{10}$. Talvez por essa razão, Veja utiliza um desenho em vez de uma figura oficial da posse.

\footnotetext{
${ }^{10}$ Ressaltamos que a edição de Veja sempre é disponibilizada de forma digital às sextas-feiras (nesse caso, em 28.12.2018), enquanto a versão impressa às terças-feiras da semana posterior. A capa em análise foi uma exceção, uma vez que a cerimônia da posse ocorreu no dia 01.01.2019, feriado universal, que coincidiu com uma terça-feira. Por esse motivo, a edição foi levada às bancas no dia seguinte.
} 
V. 11 (3) $356-385$ set-dez 2021
Figura 1 - Almanaque Bolsonaro

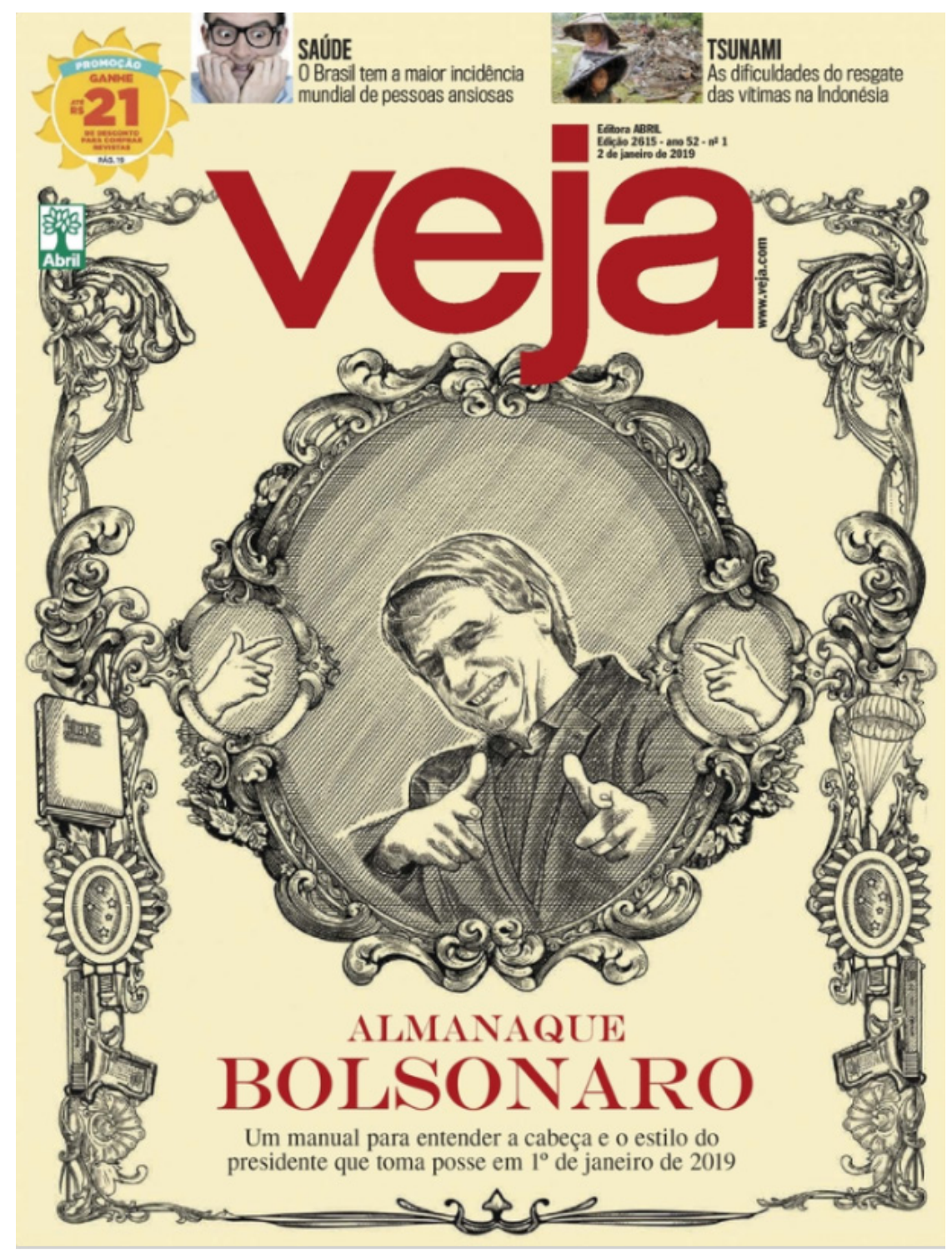

Fonte: Veja, ed. 2615, n. 1, jan. 2019a.

Embora o tempo verbal da expressão "que toma posse" esteja no presente, seu significado aponta para um futuro bem próximo, com data determinada. Acima do texto verbal, comparece a imagem do presidente, em plano médio curto. Note-se que o busto de Bolsonaro ocupa posição de destaque no centro da ilustração, com seu corpo partindo do lado direito da revista e contornado por símbolos que remetem ao seu passado militar, lembrando um espelho, um quadro ou até mesmo um camafeu.

Difundido no Brasil com a vinda da Família Real Portuguesa, o "almanaque" já era descrito como: 
livro de notícias das pessoas de ofícios públicos civis ou militares com observações meteorológicas e algumas notícias históricas e cronológicas. Livro que contém a distribuição do ano por meses e dias com as datas das festas, vigílias, mudanças da lua e folhinha (BLUTEAU; SILVA, 1789, p. 62).

Ao pesquisarmos alguns exemplares dos primeiros almanaques no Brasil, percebemos que no século XIX ele era apresentado como documento "administrativo, mercantil e industrial", chancelado pela corte e província, a fim de informar e manter um diálogo com as lideranças, haja vista que apenas as classes média e alta sabiam ler:

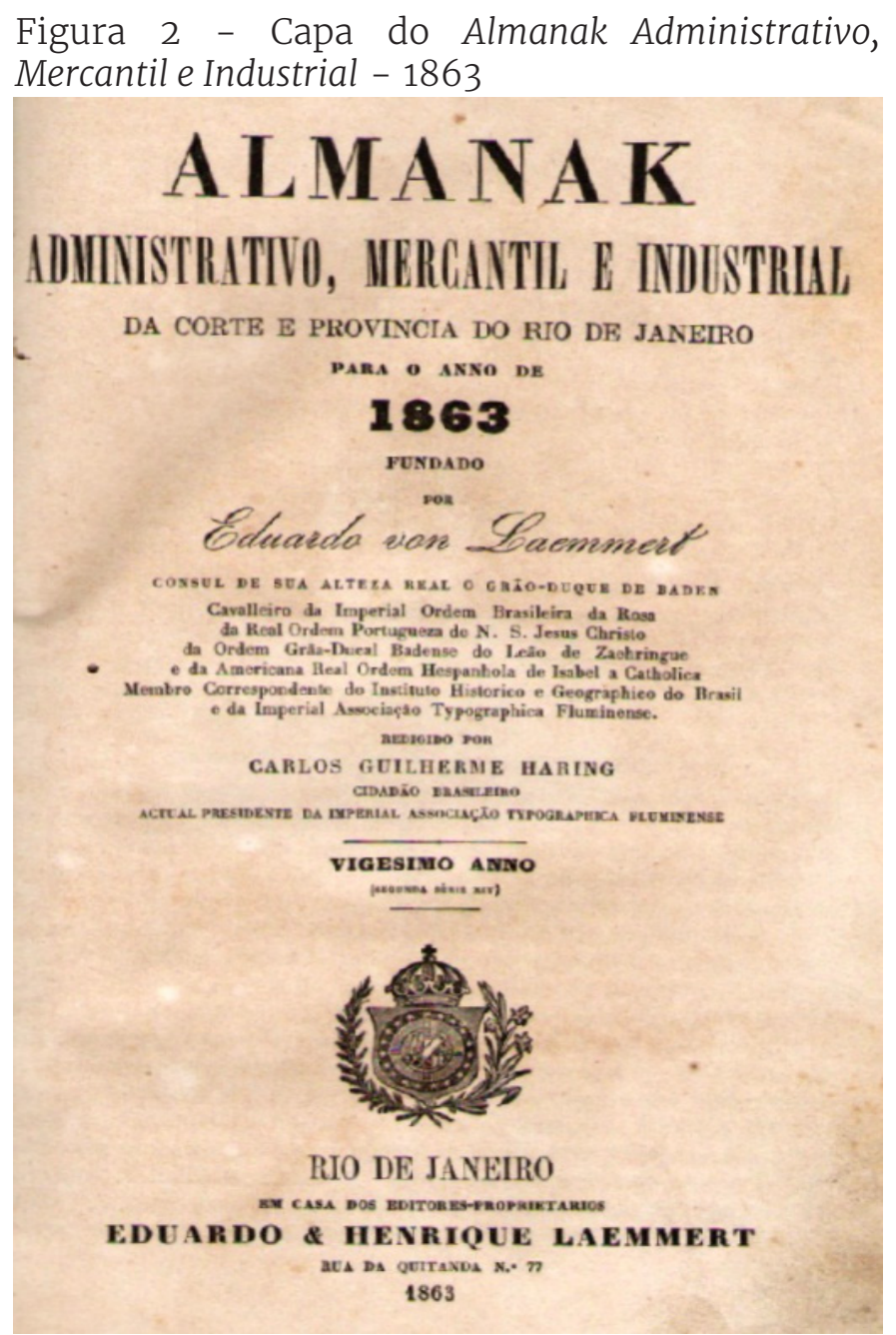

Fonte: Internet. Disponível em: https://bityli.com/oUIxj. Acesso em: 18 nov. 2020

Ao observarmos a capa do almanaque acima (Fig. 2), podemos inferir que a cor bege, assim como a apresentada no plano de fundo da capa da Veja (Fig. 1), remete à sugestão de antiguidade, de desbotado ou de idade avançada. Machado de Assis (2001, p. 26), no conto Como se inventaram os almanaques, afirmou: "[o] Tempo inventou o almanaque; 
V. 11 (3)

$356-385$

set-dez 2021

compôs um simples livro, seco, sem margens, sem nada; tão-somente os dias, as semanas, os meses e os anos". Outros aspectos importantes do conto machadiano são a popularidade dos almanaques e o registro da passagem do tempo, conforme o número de suas edições:

Quando chegou o fim do ano, toda a gente, que trazia o almanaque com mil cuidados, para consultá-lo no ano seguinte, ficou espantada de ver cair à noite outra chuva de almanaques. Toda a terra amanheceu alastrada deles; eram os do ano novo. Guardaram naturalmente os velhos. Ano findo, outro almanaque; assim foram eles vindo, até que Esperança contou vinte e cinco anos, ou, como então se dizia, vinte e cinco almanaques. (ASSIS, 2001, p. 27).

Note-se que o trecho acima apresenta outra característica dos almanaques: a publicação anual de novos fascículos. Logo, esse gênero textual incorporou aspectos experimentados na cultura popular, tais como:

[...] aforismos, conversas sobre as Artes em geral e a Literatura em particular; anedotas e versos de Cantadores; enredos em prosa e verso - conto, ensaio, memória, poesia e teatro; [...] (SUASSUNA, 2000).

Amplamente difundido, funcionou como um manual que orienta, facilita a vida dos leitores e organiza diversas informações. Para Martín-Barbero (1997, p. 151) "os almanaques são a primeira enciclopédia popular onde conselhos de higiene e de saúde se acham misturados com receitas mágicas".

Com a expansão do sistema escolar no Brasil recémrepublicano, eles passaram a ser fonte de informação e de entretenimento para as outras classes sociais. Novos elementos gráficos foram incorporados aos almanaques para atrair o leitor, como sugere esse exemplo, de 1898: 
Figura 3 - Capa do Novo Almanach de Lembranças LusoBrasileiro - 1898

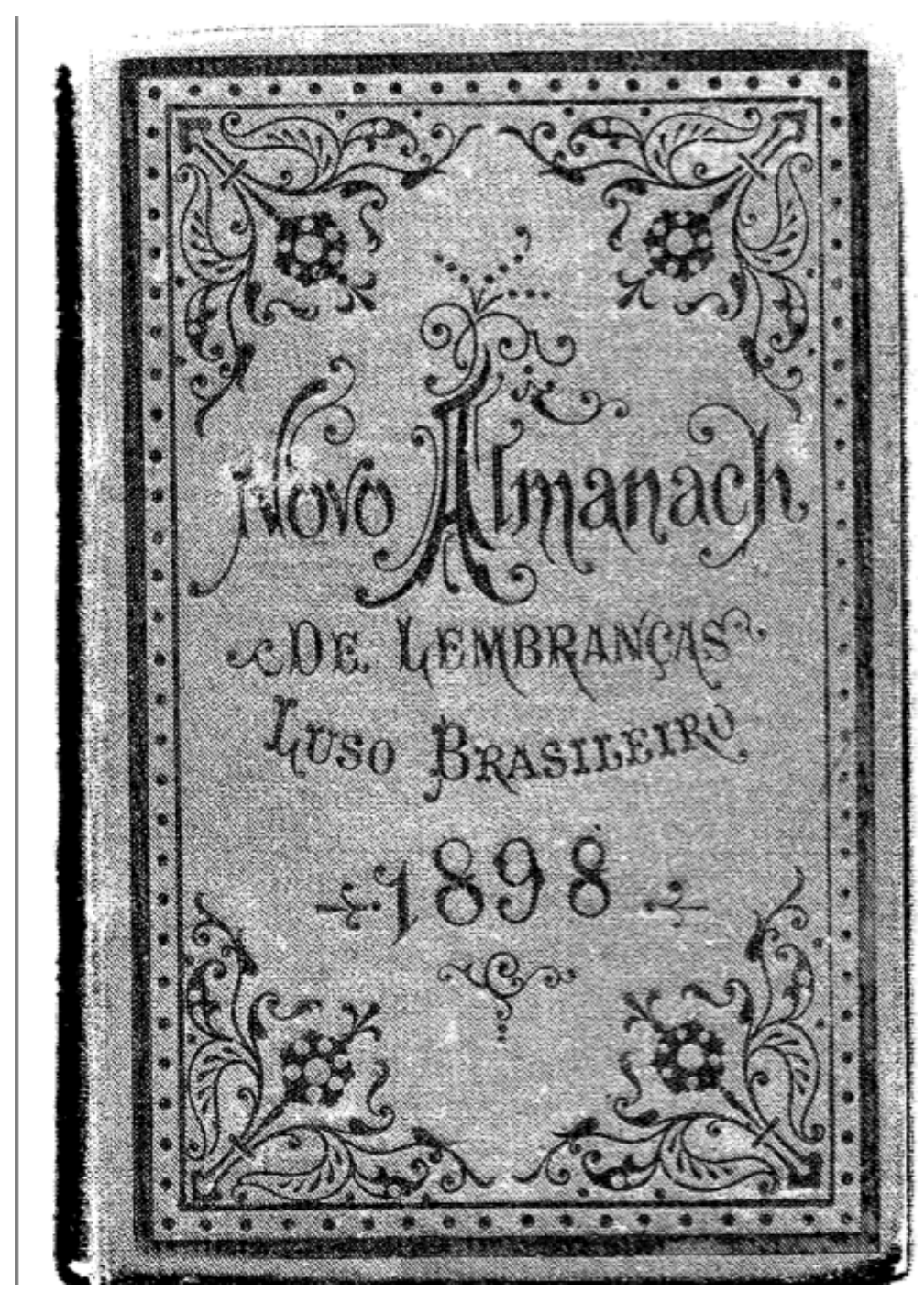

Fonte: Internet. Disponível em: https://bityli.com/Ekbna. Acesso em 11 nov. 2020.

A capa da Veja (Fig. 1), adornada com o mesmo estilo floreado dessa edição do Novo Almanach de 1898, agregou, ainda, signos que remetem às forças armadas (pistola, paraquedas, brasão, "arminha") e à religião (a Bíblia). Além disso, o título "almanaque", na margem inferior, reforça a aproximação textual da revista semanal com aquele produto midiático: assuntos variados que vão da política interna e externa à coluna social, de críticas de livros e de filmes às entrevistas com diferentes personagens. Por meio de tais estratégias verbo-visuais, Veja produz um discurso paradoxal. Por um lado, a suposta neutralidade de um periódico que, como qualquer almanaque, informa os principais acontecimentos dos últimos sete dias; mas por outro, a remissão ao conhecimento extralinguístico do leitor, ao traduzir a carreira pregressa 
V. 11 (3)

$356-385$

set-dez

2021

e as promessas de campanha do presidente recém-eleito em signos dos campos semânticos do militarismo e da religião. Outro paradoxo que se observa é a cor vermelha do título e do subtítulo, que remete à ideia de sangue, mas diluída com o bege neutro do fundo.

Igualmente importante é entender o jogo discursivo implícito nos enunciados presentes nessa capa de Veja, uma vez que as chamadas superiores (Fig. 4) também a compõem, afetando os sentidos dos demais elementos verbo-visuais. Uma vez que "toda palavra dialoga com outras palavras, constitui-se a partir de outras palavras, está rodeada de outras palavras" (BAKHTIN apud FIORIN, p. 19), para lermos a capa como um enunciado completo é preciso entender as relações dialógicas que a constroem. Temos, assim, dois enunciados que tratam sobre problemas relativos à qualidade ou à preservação da vida (aumento de ansiosos no Brasil e dificuldade de resgate de feridos e/ou sobreviventes na Indonésia) em oposição aos sentidos atribuídos à posse de um candidato da extrema-direita, reconhecido por seu apreço às armas de fogo, que ameaçam a existência.

Figura 4 - Recorte da faixa superior da figura 1
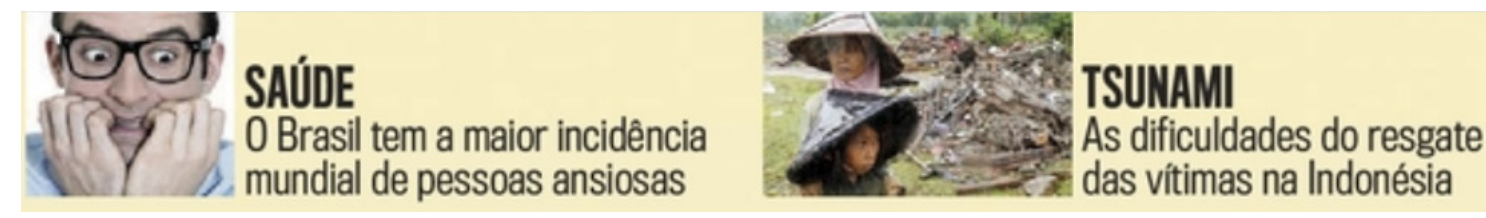

Fonte: Autores.

Já no Twitter, no dia 02 de janeiro de 2019, Bolsonaro compartilhou uma publicação da Compactor, empresa que se intitula $100 \%$ brasileira, mas criada na Alemanha ${ }^{11}$, que produz artigos de papelaria, sobretudo a popular caneta utilizada para a assinatura do termo de posse: "Nós é que agradecemos a ótima qualidade e preço da caneta!" (Fig. 5). O presidente encerra o texto com duas figuras: a forma gestual 'positivo' e a bandeira do Brasil.

\footnotetext{
${ }^{11}$ Segundo os estudos de: MENDONÇA, Carolina Bittencourt. Escrevendo uma história: a experiência da Cia. de Canetas Compactor em Nova Iguaçu (1955-1995). 2014. 52p. Trabalho de conclusão de curso (Licenciatura em História) - Instituto Multidisciplinar, Universidade Federal Rural do Rio de Janeiro, Nova Iguaçu, 2014. Disponível em: https://bit.ly/38fymZc. Acesso em: 20 nov. 2020.
} 
Figura 5 - Twitter

Jair M. Bolsonaro

@jairbolsonaro

Nós é que agradecemos a ótima qualidade e preço da caneta! $\otimes$

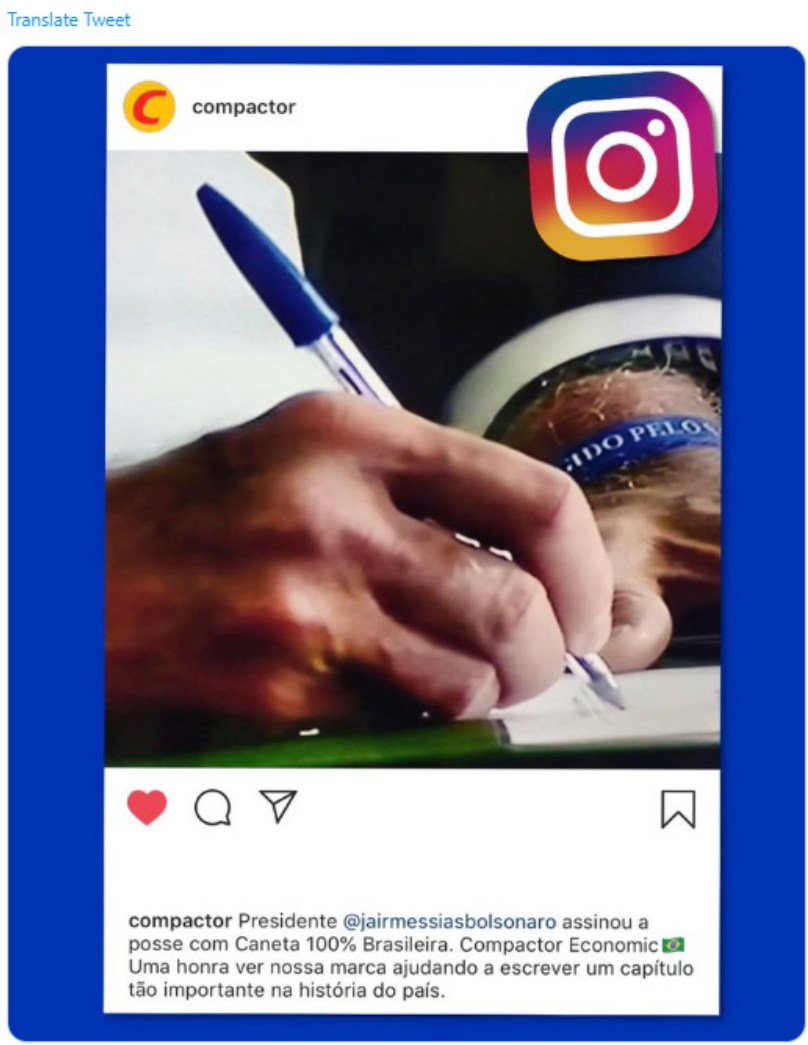

8:20 PM - Jan 2, 2019 - Twitter for iPhone

11.7K Retweets $\quad 89.5 \mathrm{~K}$ Likes

Fonte: Twitter. Publicado em: 02 jan. 2019. Disponível em: https://twitter.com/ jairbolsonaro/status/1080589678091341824 Acesso em: 30 nov. 2019.

Na postagem original da Compactor, em seu perfil da rede social Twitter, reconhecemos a imagem em close das mãos de Bolsonaro, quando assina o termo de posse com a caneta da marca, a Compactor Economic. No enunciado que segue: "Presidente @jairmessiasbolsonaro assinou a posse com Caneta 100\% Brasileira. Compactor Economic $\overline{[<0>1}$ / Uma honra ver nossa marca ajudando a escrever um capítulo tão importante na história do país" (Fig. 5), a empresa não só se autopromove, como também expressa seu apoio ao $38^{\circ}$ Presidente do Brasil. Esse enunciado parece expressar o apoio da classe empresarial brasileira ao presidente, uma vez que a agenda ultraliberal prometida por ele serve aos interesses dessa parcela da sociedade. Tal suporte tem sido expresso por meio de discursivizações diversas, como as reivindicações por diminuição de 
V. 11 (3)

$356-385$

set-dez 2021

tributos para o setor produtivo, a redução de encargos e obrigações trabalhistas e o afastamento do Estado de questões regulatórias. Assim, salientar que a caneta é produto da indústria nacional parece ser indício de uma chancela não apenas ao presidente, mas ao que sua posse representa, sob o ponto de vista das políticas econômicas para essa parcela da população. Sob uma perspectiva liberal, a ideia de que "o Brasil está acima de tudo" encontra amparo nesse tipo de expectativa sobre as prioridades do governo.

A moldura azul do post (Fig. 5) se relaciona tanto com a tampa da caneta quanto com a pulseira de silicone que Bolsonaro utiliza na mão esquerda (Fig. 6).

Figura 6 - Pulseira de Bolsonaro
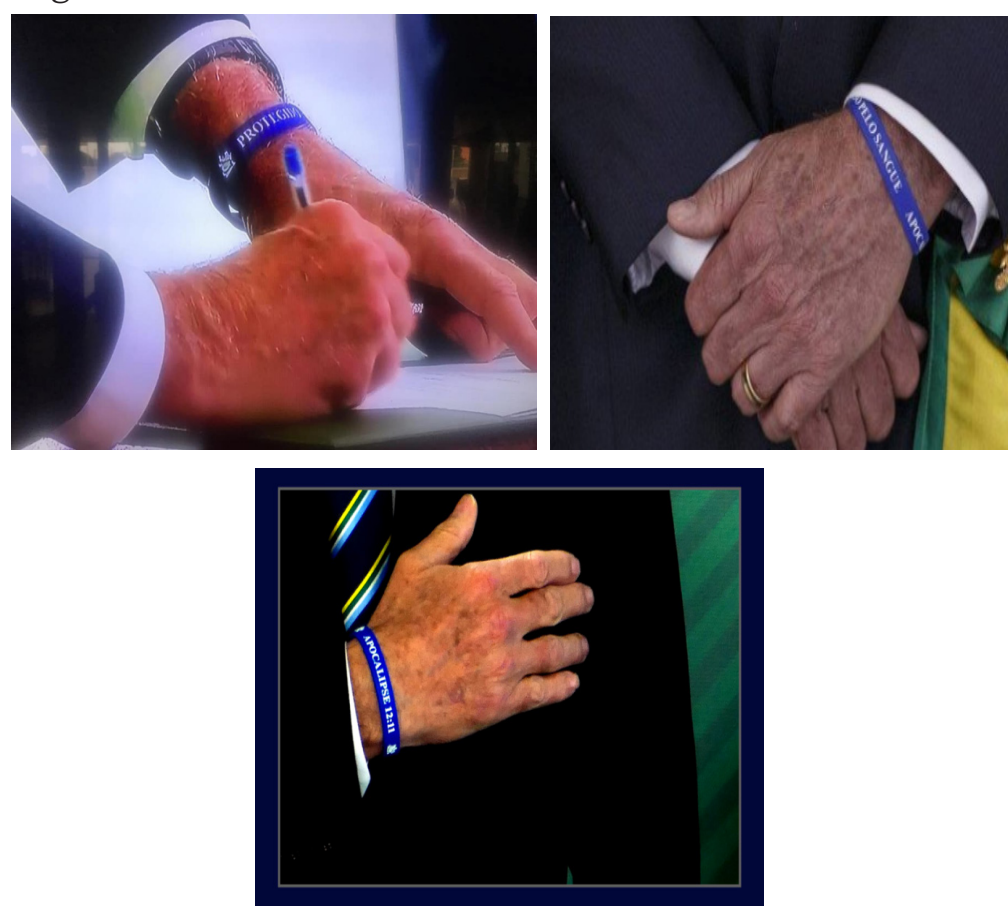

Fonte: Internet. Composição criada pelos autores.

A inscrição bíblica no adereço: "Protegido pelo sangue Apocalipse 12:11", reafirma e alimenta outra de suas pautas centrais de campanha, "Deus acima de todos", conforme o slogan de sua campanha. Este, por sua vez, remete à famigerada frase "Deutschland über alles" (Alemanha acima de todos), apregoada pelo regime nazifascista de Adolph Hitler. Vê-se, assim, como os enunciados, quando em relação dialógica, marcam as posições de seus enunciadores.

"Protegido pelo sangue" também sugere que Bolsonaro tem proteção divina ou, no mínimo, que é um de seus eleitos, haja vista a 
força associada à ideia ancestral de pacto de sangue entre dois seres humanos ou entre o humano e o divino, como explica Feldman:

Duas religiões milenares [judaísmo e islamismo] concorrem há dois mil anos, a uma mesma herança espiritual, cada qual se autodenominando herdeira de um pacto com Deus. (...) A construção das representações sobre as origens do Judaísmo tende a colocar o sangue na origem do pacto de Deus com Abraão e sua descendência (2013, p. 2-5).

As cores da pulseira também remetem à bandeira de Israel, país com o qual o bolsonarismo se alinha por motivos de natureza diversa. Trata-se, portanto, de um enunciado verbo-visual que reforça o vínculo de Bolsonaro com o campo da religião, mas em um contexto eminentemente político. Muito embora a cerimônia de posse de um presidente sempre seja marcada por uma série de rituais, sua assinatura, em close, nos documentos oficiais, ganhou destaque midiático. Essa veiculação da Compactor foi pensada e dirigida, pois graças à substituição da tradicional Montblanc ${ }^{12}$ por uma caneta comum, empresa e presidente reforçaram sua identificação com o grande público. Acrescente-se a essa estratégia a posição que Bolsonaro ocupa ao se expressar verbalmente, com imprecisão vocabular, palavrões e cacoetes, muito próxima da linguagem popular.

Nessa imagem, compartilhada na internet por mais de 11 mil pessoas, com mais de 89 mil likes, reconhecemos elementos da espetacularização, como explica Marcondes Filho:

a resposta e a saída que as sociedades regidas pela economia onipotente dão a si mesmas, reconhecendo-se nos seus produtos metamorfoseados não mais no ter, mas agora na grande ideologia que é o parecer (2009, p. 175, grifos do autor).

Assim, a imagem de uma pessoa que apenas parece humilde, desapegada de objetos luxuosos, poderia ser contestada pelo padrão de vida da família Bolsonaro. Em sua declaração de bens ao Tribunal Superior Eleitoral em 2018, seus rendimentos oficiais somavam a importância de $\mathrm{R} \$$ 2.286.779,48 ${ }^{13}$ diluídos em aplicações financeiras, casas, carros importados e ações de empresas. Podemos reconhecer novamente outro indício da espetacularização, como ensina Marcondes

\footnotetext{
${ }_{12}$ Caneta de grife utilizada em atos oficiais em grande parte do mundo, que confere, simbolicamente, status superior ao seu proprietário ou usuário.

${ }_{13}$ Tribunal Superior Eleitoral. Divulgação de Candidaturas e Contas Eleitorais. Página de Jair Bolsonaro. Disponível em: http://bit.ly/2LIv2hv. Acesso em 01 dez. 2019.
} 
V. 11 (3)

$356-385$

set-dez

2021

Filho, uma vez que o presidente busca se identificar apenas na aparência com os estratos mais pobres da população brasileira.

Outras postagens de Bolsonaro do dia 02 de janeiro de 2019 no Twitter se resumem aos agradecimentos, às congratulações recebidas por outros chefes de Estado e à confirmação de seu discurso de posse.

Um aspecto que nos chama a atenção é a aproximação simbólica entre a capa da revista (Fig. 1) e a caneta (Fig. 5), pois a mesma mão que a segura é a mesma que representa o "gesto de arma" e a que executa o "ato de assinar sua posse", respectivamente.

Muito utilizado em toda sua campanha eleitoral, o gesto de arma viralizou entre seus apoiadores, ou seja, "é uma visão de mundo que se objetivou" (DEBORD, 1997, p. 14), transformando-se em um espetáculo. Para Debord, "a linguagem do espetáculo é constituída de sinais da produção reinante, que são ao mesmo tempo a finalidade última dessa produção" (1997, p. 15). Logo, a representação da posse do novo chefe de Estado aponta criticamente o que estava por vir. É o que aprendemos com Marcondes Filho (2009, p. 175), quando afirma que o "espetáculo seria o modo de representação no qual as imagens se autonomizam e ganham vida própria". Esse gestual ganhou tamanha independência e visibilidade que sua mera reprodução, por qualquer pessoa, independentemente de seu grupo social ou faixa etária, passou a significar, também no âmbito discursivo, aderência ao ideário bolsonarista, ainda que sem a reprodução verbo-visual de seus pronunciamentos.

A história política ocidental, para ficarmos apenas nela, está impregnada de gestuais que vão desde o "V" da vitória de Winston Churchill, até a saudação nazista e o passo de ganso nos desfiles militares, durante a Segunda Guerra Mundial. A mera imitação de qualquer um desses gestos atravessa a ideia de espetáculo e alcança os sentidos que representam.

A segunda capa analisada, publicada em o9 de janeiro de 2019 e intitulada "Agora é para valer: Bolsonaro assume com discurso raso, mas começa a governar sob um clima de otimismo" (Fig. 7), refere-se à cobertura do dia da posse e apresenta Jair Bolsonaro e a primeira-dama durante desfile em carro aberto em Brasília. 


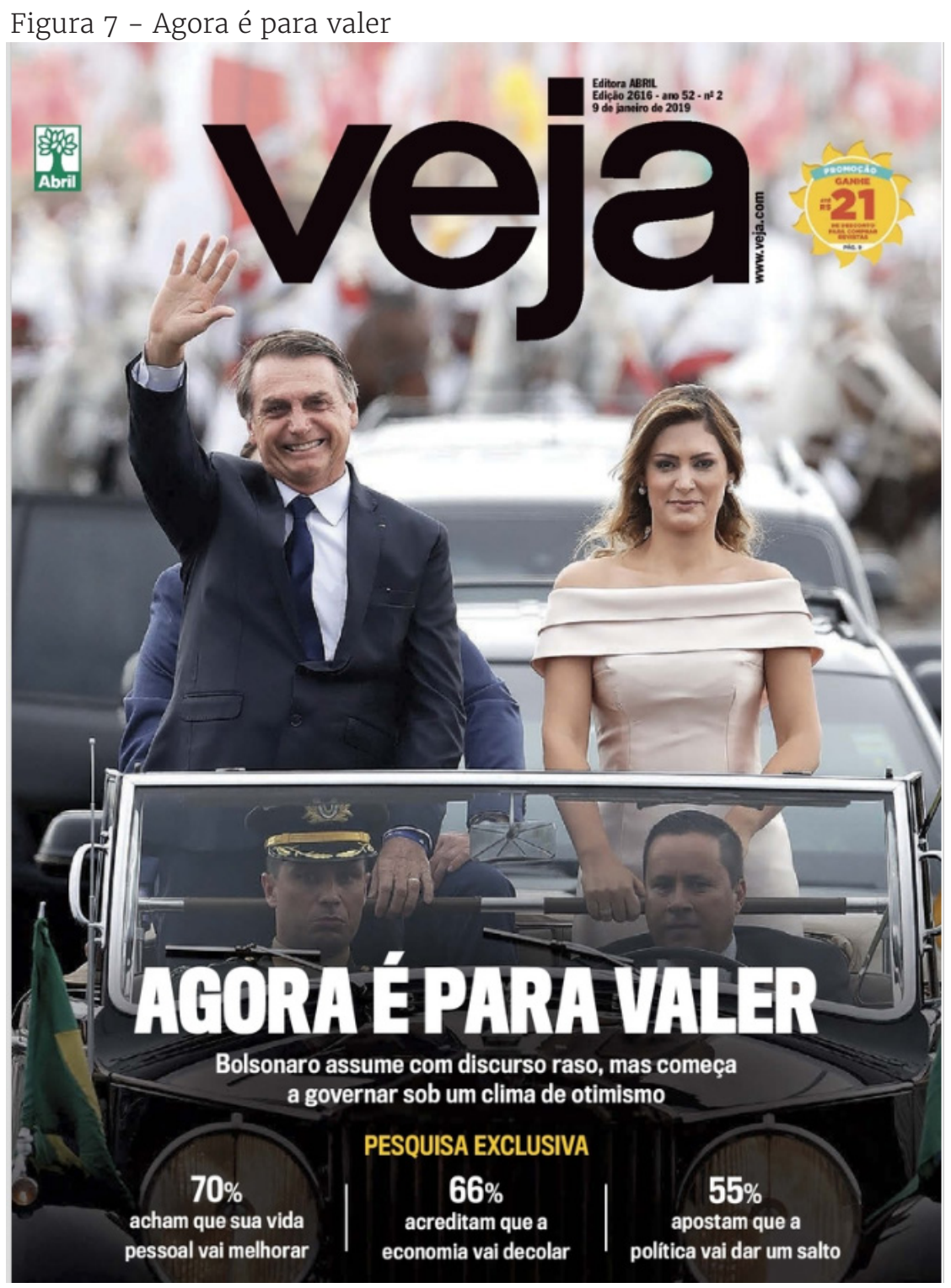

Fonte: Veja, edição 2616, ano 52, n. 2, jan. 2019 b.

Observa-se que o foco da imagem está no quadrante central, imediatamente abaixo do nome da revista na cor preta, culturalmente entendida no ocidente como morte ou luto. No plano inferior estão o carro oficial, seu condutor e um militar, assim como os subtítulos e os intertítulos brancos e amarelo, cores culturalmente associadas à paz ou à luz e à fartura. Percebemos, ainda, a formalidade da ocasião pelas vestimentas do casal presidencial, do motorista, do seu copiloto e também pelo modelo do automóvel. Apesar do sorriso contido da primeira-dama e da alegria de seu marido, os protagonistas dessa narrativa verbo-visual, podemos depreender a manifestação de pelo menos duas antíteses na capa em análise: escuridão X luz e morte X paz, graças à escolha do responsável pelo seu layout na coloração de títulos e intertítulos. 
V. $11(3)$ $356-385$ set-dez 2021

O movimento do veículo oficial, em direção ao leitor da capa, reforça o enunciado "Agora é para valer". Não há mais volta. O passado ficou para trás, misturado com os cavaleiros desfocados, ao fundo da imagem. À frente, encontra-se o futuro que só a comitiva enxerga. O mandato iniciou.

Os dados concretos e otimistas anunciados no terço inferior da imagem (Fig. 8) anulam a negatividade do adjetivo "raso", atribuído ao discurso de Bolsonaro. A positividade dos 70\%, 66\% e 55\% que acreditam nas melhorias das vidas privadas e pública equilibra a tensão discursiva apontada nos parágrafos anteriores.

Figura 8 - Recorte da faixa inferior da figura 7

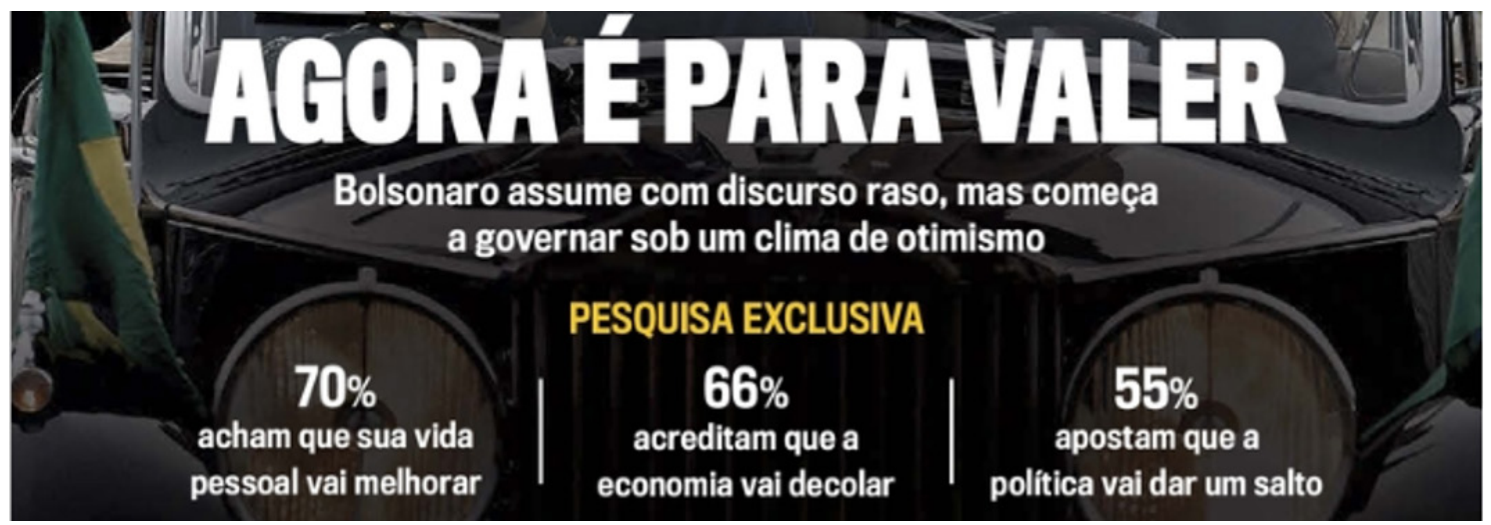

Fonte: autores.

Mas também existe a sanção: Bolsonaro, afinal, não está só. Além do público que não se vê, sua esposa ao lado confirma o imaginário da tradicional família brasileira: casal branco, heterossexual, esposa discreta, mais jovem e mais baixa que o marido.

Já no Twitter do mesmo dia, Bolsonaro se descola da cerimônia de posse e se volta às discussões acerca do pacto migratório (Fig. 9), assunto sequer mencionado pela revista, uma vez que a mídia impressa não acompanha os acontecimentos em tempo real como as digitais.

Em discurso oposto ao dos Direitos Humanos, Bolsonaro qualificou o migrante como "qualquer um" e explicitou os critérios essenciais para permitir seu ingresso em nosso território: estar sujeito às leis, regras e costumes do Brasil; cantar o hino nacional e respeitar nossa cultura.

A composição imagética dos posts no Twitter (Fig. 9) prioriza o texto verbal do presidente, transcrito tal como proferido, como indicam as aspas. As expressões verbais de que se utiliza: "deverá cantar" "[deverá] respeitar", mostram o tom ameaçador e autoritário, imediatamente após sua posse, sobre um assunto de importância global: os deslocamentos 
humanos forçados. Sem qualquer atenuante, antecipou a medida que já deveria ter em mente: em 18 de março de 2019 anunciou a isenção de vistos para a entrada no Brasil de estrangeiros nascidos nos EUA, Japão, Austrália e Canadá, considerados desenvolvidos. Contudo, vale destacar que tal benefício não foi recíproco aos brasileiros, que ainda dependem de autorização para visitar tais países.

Desse modo, enquanto no Twitter Bolsonaro se mostra rígido sobre a migração, na prática, anuncia pouco depois a isenção de vistos para algumas nações, fazendo valer, mais uma vez, o "parecer" ao invés do "ser", prática recorrente dos políticos da extrema direita.

Figura 9a - Pacto Migratório
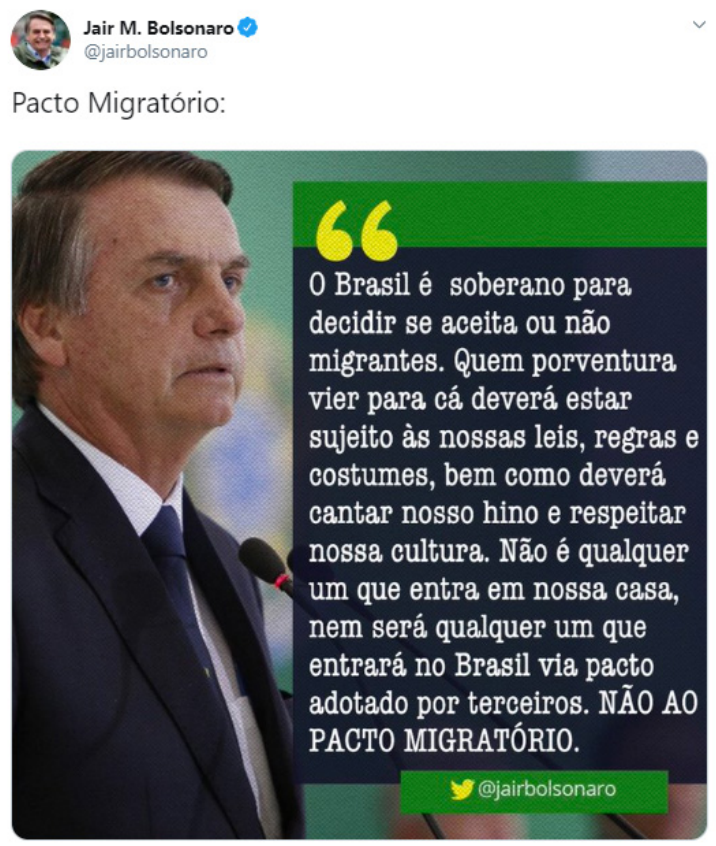

Figura 9b - Pacto Migratório

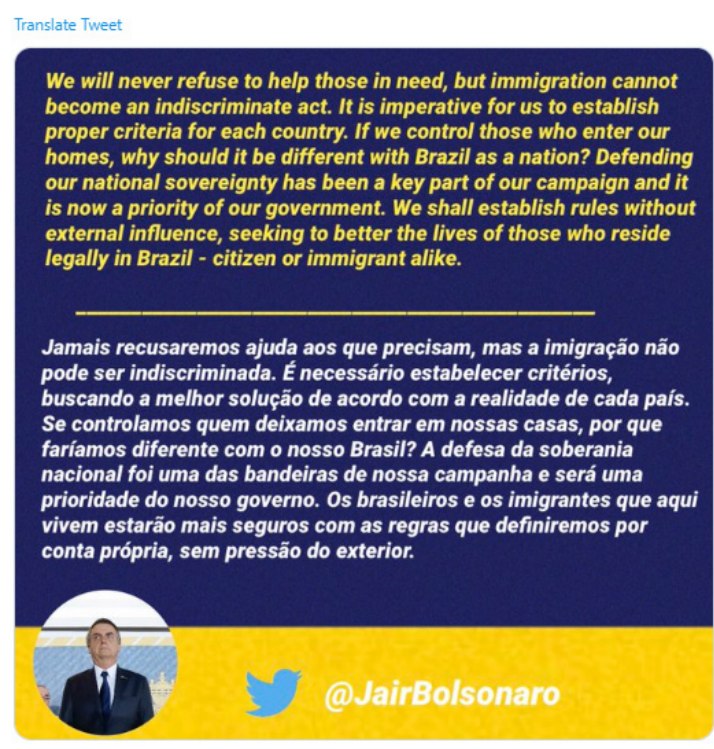

2:30 PM · Jan 9, 2019 - Twitter for iPhone

3.2K Retweets $\quad 20.7 \mathrm{~K}$ Likes

6:57 AM · Jan 9, 2019 - Twitter for iPhone

7.3K Retweets $\quad 42.9 \mathrm{~K}$ Likes

Fonte: Twitter. Publicado em: 09 jan. 2019. Disponível em: https://twitter.com/ jairbolsonaro/status/1082924268361519104. Acesso em: 15 nov. 2019.

O texto foi parcialmente traduzido para o inglês (Fig. 9b), o que mostra a preocupação de Bolsonaro para ser entendido em escala mundial. Ao mesmo tempo, o trecho flagrou sua ideologia, pois o cuidado não se estendeu às frases iniciais, as mais ameaçadoras (Fig. 9a). Ou, então, se tratou de uma ação planejada: ao omitir certas passagens, o capitão reformado do exército lançou luz sobre as demais e assim construiu a imagem de um líder mais afável para os estrangeiros do que para os brasileiros. Como se dá esse processo? Basta reconhecer que no 
V. 11 (3)

$356-385$

set-dez

2021

texto exclusivamente em língua nacional, Bolsonaro emprega verbos ligados aos campos semânticos da ameaça e do poder: "soberano para decidir", "soberano para aceitar", "deverá estar sujeito", "não é/não será qualquer um". Trata-se, portanto, de um discurso centrípeta, isto é, que tenta conter a dispersão, a heterogeneidade, e é indicadora de uma formação social ligada ao poder (Bakhtin, 2015).

Esses enunciados carregam juízo de valor ou paixões de seu locutor, diferentemente de "palavras soltas", que caracterizam a neutralidade da língua. Tal lição mostra-se mais didática nos escritos de Bakhtin:

[...] toda palavra comporta duas faces. Ela é determinada tanto pelo fato de que procede de alguém, como pelo fato de que se dirige para alguém. Ela constitui justamente $o$ produto da interação do locutor e do ouvinte. Toda palavra serve de expressão a um em relação ao outro. Através da palavra, defino-me em relação ao outro, isto é, em última análise, em relação à coletividade. A palavra é uma espécie de ponte lançada entre mim e os outros. Se ela se apoia sobre mim numa extremidade, na outra apoia-se sobre meu interlocutor. A palavra é o território comum do locutor e do interlocutor. (1999, p. 113).

Já na segunda parte da narrativa (Fig. 9b), a ameaça se transforma em explicações, genéricas e vagas: "estabelecer critérios, buscando a melhor solução para cada país"; "estarão mais seguros com as regras que definiremos por conta própria".

Não fica claro a que novo conjunto de regras Bolsonaro se refere para pensar os migrantes, mas é explícita sua recusa em aceitar o que já estava em andamento. Ao escrever "NÃO AO PACTO MIGRATÓRIO", ele mostra que já havia algo em discussão e as letras maiúsculas enfatizam graficamente sua reprovação.

Vemos, assim, que se no Twitter o texto de Jair Bolsonaro se descola da cerimônia de posse tão bem representada em Veja, em contrapartida entra em relação dialógica com a migração mundial, um dos fenômenos sociopolíticos mais graves da contemporaneidade.

As cores amarela, verde e azul, que acompanham o texto do presidente, reproduzem as da bandeira nacional e reforçam o bordão "Brasil acima de tudo e Deus acima de todos". Portanto, "conhecer nossos costumes", um dos itens obrigatórios para a permanência de um estrangeiro no país, ganha ares de coerência e de intertextualidade.

Seu semblante sério no Twitter difere do largo sorriso que exibe na capa da Veja, mas seu figurino aparenta ser o mesmo do dia da 
posse. A impressão que se tem é que a postagem no Twitter ocorreu após a cerimônia, dado que se confirma pela data estampada: 09/01/2019.

Temos, assim, que enquanto a capa da Veja estampa o ritual da festa do novo presidente, o Twitter já expõe suas primeiras ações. Se pensarmos em uma narrativa linear, veremos que a construção discursiva desse novo personagem é ambígua pois, enquanto emissor de discursos, Jair Bolsonaro é pouco competente, porém pródigo nas frases de sentidos amplos e nas frases de efeito. Além disso, ele exibe um gestual que varia da alegria à sobriedade.

Finalmente, mas não menos importante, é a sobreposição do corpo de Bolsonaro à imagem de seu filho, Eduardo, na capa da Veja (Fig. 7). Como em Análise do Discurso todos os elementos são igualmente importantes, esse apagamento merece ser destacado.

Considerado um dos seus conselheiros, Eduardo Bolsonaro, em 2018, foi um dos deputados federais mais votados na história do país, com mais de 1,5 milhões de votos. Sua projeção na vida política brasileira parece, portanto, bastante consolidada, diferentemente da de seu pai, mais lembrado por sua carreira militar do que por ações no Legislativo. Talvez por isso Veja tenha optado por colocar na capa apenas o casal Bolsonaro, deixando para trás aquele que viria a se tornar um dos elementos-chave para a gestão do novo governo.

A ausência de outros elementos imagéticos ou textuais na capa de Veja reforça a hipótese acima: era necessário destacar a nova gestão e não distrair a atenção do leitor com assuntos de menor envergadura.

Espetacularizada, a posse de Jair Bolsonaro, na versão de Veja, mostra otimismo, estado de ânimo que confirma os primeiros propósitos da revista, desde os idos anos de 1968 (Veja, edição 1, set. 1968, p. 21): "informação rápida e objetiva", "acompanhar o extraordinário". Certamente se trata de um evento "fora do comum" (Veja, edição 1, set. 1968, p. 21), uma vez que a tensão semântica do enunciado "discurso raso", proferido pelo recém-empossado presidente, é contradita pelos números de seus apoiadores: "70\% acham que a vida pessoal vai melhorar";" 66\% acham que a economia vai decolar" e "55\% apostam que a política vai dar um salto". As expressões verbais que acompanham tais percentuais - "vai melhorar", "vai decolar", "vai dar um salto" reforçam a construção da imagem que se aproxima da do herói, cujas soluções mágicas para os graves problemas do país serão rapidamente implementadas. Também expressam a crença dos respondentes da pesquisa e do aval dos responsáveis pela edição final da capa. O Brasil, 
V. 11 (3)

356-385

set-dez 2021 portanto, não vai apenas "melhorar", mas vai "saltar" e "decolar". Tal gradação revela otimismo, decorrência natural após a conclusão de um processo eleitoral democrático.

Reconhecemos novamente como espetáculo e discurso se retroalimentam e ao mesmo tempo estabelecem conflitos, como é próprio de qualquer situação comunicacional. A imagem em primeiro plano, com o presidente acenando e sorrindo, ladeado por sua esposa em carro aberto, e com o fundo desfocado, (Fig. 7) sugere que a comitiva se estende até o infinito, ampliando, assim, o espetáculo que se vê e o que também não se vê. No entanto, as legendas que a acompanham instalam outros sentidos que, como já vimos, contradizem o otimismo e a crença nessa nova governança. Cabe ao leitor fazer a síntese e escolher a qual deles irá aderir.

Já a terceira capa, publicada em 16 de janeiro de 2019 (Fig. 10) com o título "Confusão na largada: desmentido três vezes pela própria equipe, Bolsonaro cria desordem na estreia do seu governo", apresenta a imagem do presidente eleito em escala cinza, com fundo totalmente branco:

Figura 10 - Confusão na largada

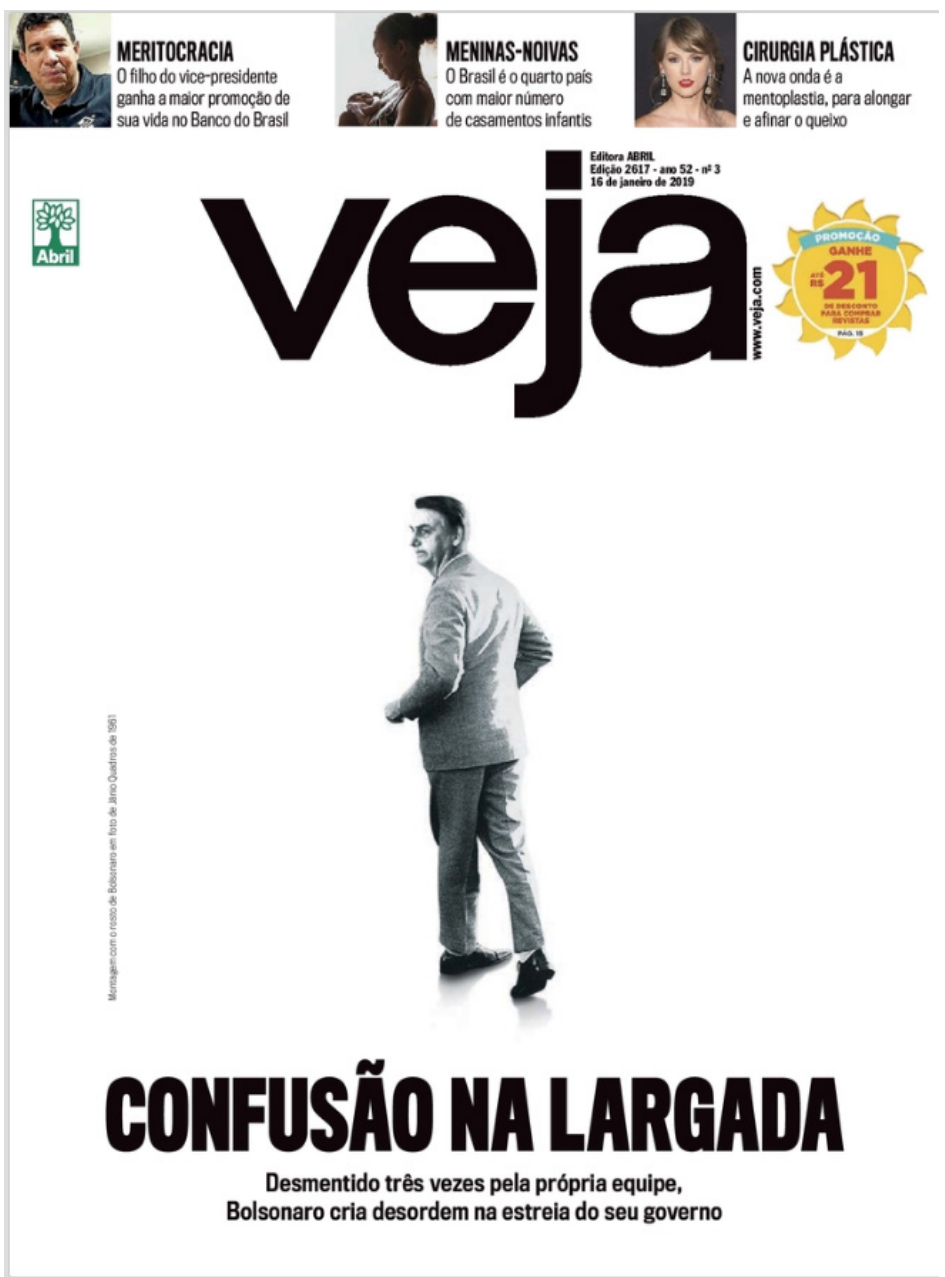

Fonte: Veja, ed. 2617, n. 3, jan. 2019c. 
É importante destacar que a cor branca contrasta com a preta das tipografias e da própria figura humana retratada em cinza. Essa edição, veiculada quinze dias após a posse de Bolsonaro, apresenta-o de corpo inteiro, e estabelece intertextualidade com a fotografia tirada pelo jornalista Erno Schneider em 21 abril de 1961 do ex-presidente Jânio Quadros (Fig. 11). Seus pés tortos, clicados durante a mudança de direção do seu corpo, indicam indefinição política do "homem da vassoura", uma vez que poderiam encaminhá-lo tanto para a direita, quanto para a esquerda, apesar da presença de militares fardados à sua frente:

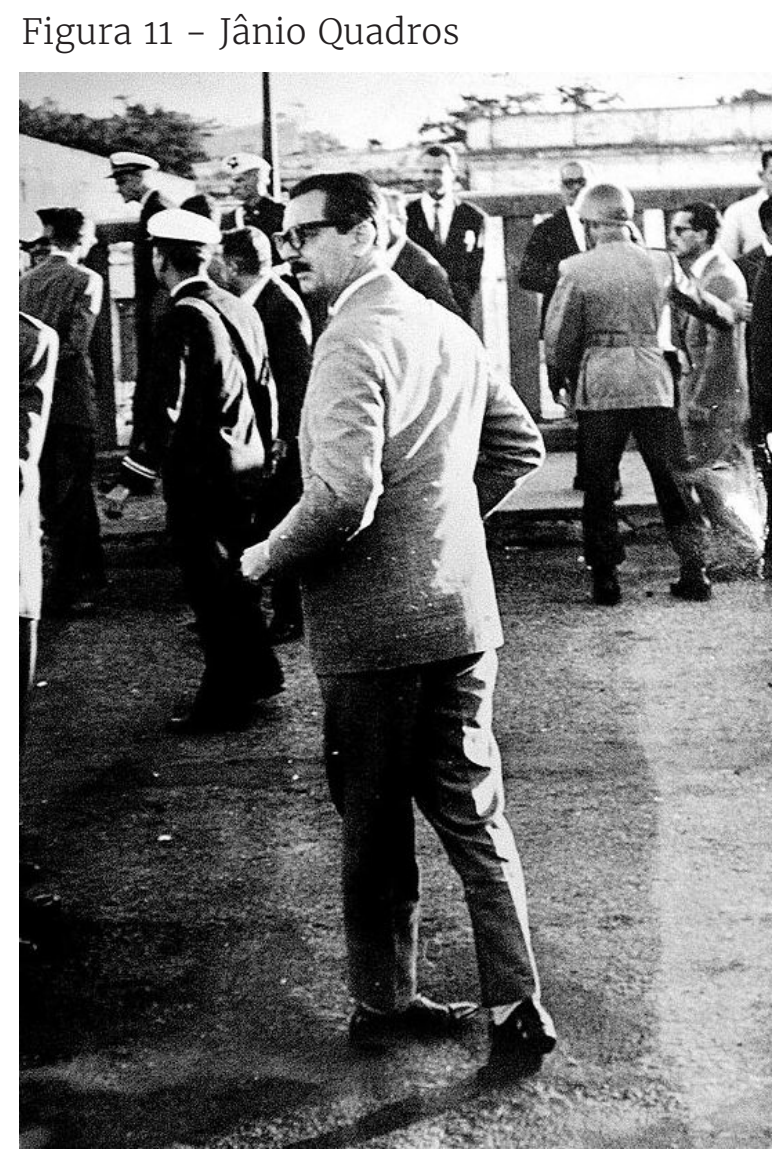

Fonte: Aventuras na História. Uol. Disponível em: https://bityli.com/qughy Acesso em: 02 dez. 2019.

A revista produz uma fotomontagem na qual substitui a cabeça de Jânio pela de Bolsonaro. A partir desse enunciado visual reconhecemos dialogismo entre as imagens, uma vez que Jânio ficou conhecido por seu breve governo com intensas contradições e polêmicas, como, por exemplo, proibir o biquíni e o lança-perfume, condecorar Che Guevara, entre outros. Sob forte pressão, ele renunciou ao cargo no oitavo mês de mandato. 
V. 11 (3)

$356-385$

set-dez

2021

Assim como na fotografia original, a capa da Veja (Fig. 10) mostra um Bolsonaro confuso, sem saber qual direção seguir, no meio do nada. O fundo branco, do qual os militares dos tempos de Jânio desapareceram, reforça a impressão de vazio. Logo, entendemos pelo dialogismo estabelecido que o novo presidente, nos quinze primeiros dias de governo, é um Jânio Quadros atualizado. Mikhail Bakhtin explica que:

As relações dialógicas são possíveis não apenas entre enunciações integrais (relativamente), mas o enfoque dialógico é possível a qualquer parte significante do enunciado, inclusive a uma palavra isolada, caso esta não seja interpretada como palavra impessoal da língua, mas como signo da posição semântica de um outro, como representante do enunciado de um outro, ou seja, se ouvimos nela a voz do outro (2010, p. 210).

Essas construções de sentido são também marcadas pelo sincretismo verbo-visual, já que o título anuncia "confusão na largada", o subtítulo aponta "desmentido" e "desordem" na "estreia" do presidente. A imagem, assim, valida os enunciados do texto ao mostrálo sozinho e desequilibrado.

Das três chamadas na parte superior da capa (Fig. 12), apenas a que se refere à meritocracia estabelece relação de sentido com a imagem predominante, pois parece ilustrar o funcionamento da sociedade patriarcal vigente e hegemônica que validou Bolsonaro nas urnas. Essa relação dialógica é facilmente estabelecida quando lemos reportagens como a que segue, intitulada "Bolsonaro elege filhos com votação recorde", da DW"

A popularidade de Jair Bolsonaro (PSL) nas urnas respingou nos filhos. Eduardo Bolsonaro tornou-se o deputado federal mais votado da história do Brasil (...).

Já Flávio Bolsonaro, eleito quatro vezes deputado estadual pelo Rio de Janeiro, deixou para trás outros 16 concorrentes e conquistou a primeira das duas vagas no Senado com $32 \%$ dos votos. (...).

As demais manchetes, "meninas noivas" e "cirurgia plástica", não colaboraram para construir efeitos de sentido na imagem do presidente. 
Figura 12 - Recorte da faixa superior da figura 10

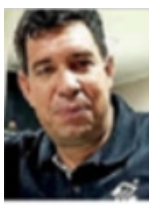

\section{MERITOCRACIA}

0 filho do vice-presidente

ganha a maior promoçà de sua vida no Banco do Brasl

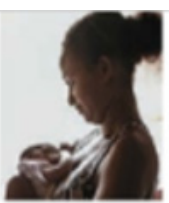

MENINAS-NOIVAS

OBrasilé o quarto pa's

com maior nùmero

de casamentos infantis

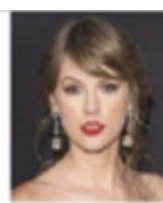

CIRURGIA PLÁSTICA

A nova ondaéa

mentoplastia, para alongar e afinar 0 quelio

Fonte: autores.

Já no Twitter, Bolsonaro anuncia seu encontro com o presidente da Argentina (Figs. 13 e 14):

Figura 13 - Bolsonaro informando a visita de Macri

Jair M. Bolsonaro

@jairbolsonaro

Hoje, às 10:30, receberei o Presidente da Argentina,

@mauriciomacri.É a primeira visita oficial de um Chefe de Estado ao Brasil desde a minha posse. Uma grande oportunidade de reforçar os laços de amizade com essa nação irmã! $\theta$

Translate Tweet

9:27 AM · Jan 16, 2019 - Twitter for iPhone

5.6K Retweets $53 \mathrm{~K}$ Likes

Fonte: Twitter. Publicado em: 16 jan.

2019. Disponível em: https://twitter.com/ jairbolsonaro/status/1085498743720427520?ref_ src=twsrc\%5Etfw Acesso em: 20 nov. 2019.

Figura 14 - Maurício Macri e Jair Bolsonaro

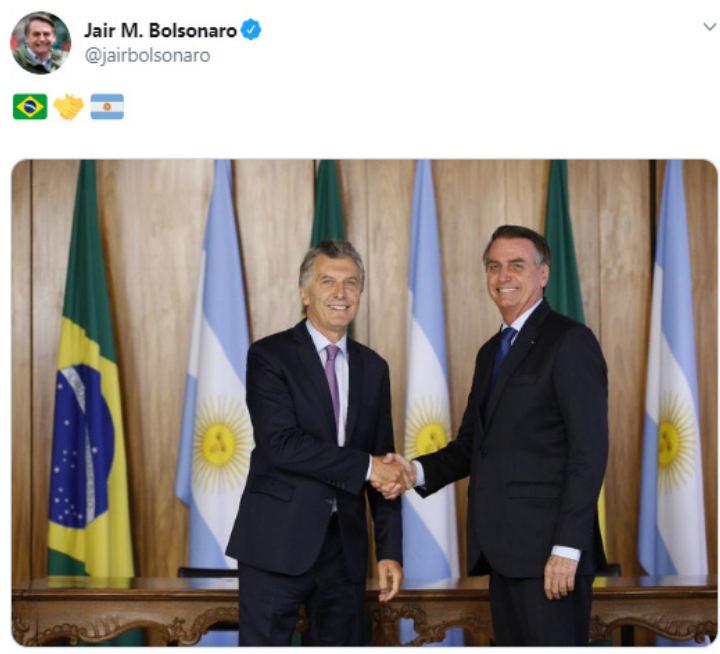

1:31 PM · Jan 16, 2019 · Twitter for iPhone

$$
\text { 5.8K Retweets } \quad 61.4 \mathrm{~K} \text { Likes }
$$

Fonte: Twitter. Publicado em: 16 jan. 2019. Disponível em: https://twitter.com/ jairbolsonaro/status/1085560219730673671. Acesso em: 20 nov. 2019. 
V. 11 (3)

$356-385$

set-dez

2021

Como para Debord "[...] o mundo real se converte em simples imagens, estas simples imagens tornam-se seres reais" (1997, p. 19), não fica muito claro, afinal, a que "laços de amizade" Bolsonaro se refere em seu texto. Certamente não se trata de solidariedade à "nação irmã", uma vez que no dia de sua posse, apenas quinze dias antes do encontro, a relação entre os dois países encontrava-se instável, por conta de desavenças em torno do Mercosul.

Logo, pode-se observar que a aparência de cordialidade recíproca nada mais é do que um espetáculo, que faz crer, graças à mediação das imagens. Não fosse assim, o presidente brasileiro teria feito sua primeira viagem internacional à Argentina, mas preferiu o Chile.

\section{Considerações finais}

Vimos nesse artigo a importância de se analisar as disputas de sentidos de Jair Bolsonaro nas duas maiores mídias em número de leitores ou de seguidores: as capas de Veja e os tweets na conta do presidente, respectivamente, no primeiro mês de seu mandato.

Veja, por meio de relações dialógicas explícitas e implícitas, mostrou-se crítica ao governo de Jair Bolsonaro em suas capas ainda antes de ele tomar posse. Ressalta-se que, em seus primórdios na década de 1960, os editores disseram que a missão da revista seria informar o Brasil rápida e objetivamente, "a fim de escolher rumos novos". Dessa forma, as edições analisadas não hesitaram em construir textos verbovisuais com a ameaça que rondava o futuro do país, em uma espécie de "crescendo".

Se a primeira edição, a do "almanaque", era para instruir os leitores sobre "a cabeça e o estilo" do novo presidente (Fig. 1), a edição seguinte já anunciava o discurso "raso" de Bolsonaro (Fig. 7) para, na última (Fig. 10), afirmar que já fora "desmentido três vezes pela própria equipe", criando "desordem em sua estreia". Isso quer dizer que, sob a ótica de Veja, em um intervalo próximo a um mês, o Brasil passou de um estado de apreensão do que estava por vir para a desorientação do chefe da nação, já em exercício de seu mandato.

Em nenhuma dessas capas foi possível reconhecer a voz dos leitores, tampouco a do presidente, o que mostra que o dialogismo se estabeleceu fora do texto, isto é, entre a revista e outros enunciados em circulação, conhecidos e reconhecidos pelo público leitor. No entanto, 
a maneira com a qual o discurso sobre Jair Bolsonaro foi construído mostra que Veja também acabou por praticar o discurso centrípeta, a fim de uniformizar o sentido que desde o início atribuiu ao novo governo. As outras vozes extratextuais com as quais a revista dialoga, como a dos que responderam à pesquisa sobre a avaliação do futuro governo, não estão em condição de igualdade com ela.

Os tweets do presidente, no entanto, tentam edificar sua imagem. No primeiro, também de 02 de janeiro de 2019 (Fig. 5), no lugar da festa em espaço público, reconhecemos a presença da pulseira de silicone no pulso do presidente, com cores que remetem a Israel, enunciados que remetem ao campo da religião, e uma caneta de baixo custo. Não é nem necessário mostrar seu rosto. Suas mãos representam o corpo inteiro e, suas roupas formais, o cargo que abraçara. Assim, pode-se construir a imagem de um chefe da nação que dispensou pompa e circunstância e que logo em seguida entrou em ação.

Em seguida, em o9 de janeiro, temos o anúncio, com cores que conversam com a bandeira nacional e texto em língua inglesa, das medidas autoritárias e imprecisas para conter o fluxo migratório (Figs. 9a e 9b). Finalmente, no último tweet, de 16 de janeiro, Bolsonaro encontrou-se com o presidente da Argentina (Figs. 13 e 14) e assim mostrou serviço no cenário internacional.

Temos, portanto, duas narrativas distintas: enquanto em Veja Bolsonaro é desconstruído nos dias que separam a primeira capa - a do Almanaque (Fig. 1) - da terceira, em que é comparado com Jânio Quadros (Fig. 10), seus tweets tentam mostrar o contrário. O presidente, tão logo assinou os documentos que lhe asseguraram o novo cargo, tratou de questões sociais, como os migrantes e a política comercial, ao recepcionar Maurício Macri.

Vimos, ainda, a importância das imagens verbo-visuais que corroboram a ideia de Guy Debord. A espetacularização que os textos contêm é disfarçada ou até mesmo negada por enunciados que resultam em significados distintos. Ou seja: as imagens que compõem essas figuras parecem ter autonomia e vida própria, mas são atravessadas por outros sentidos discursivos. É na relação entre os conceitos que trouxemos aqui - espetáculo e discurso - que podemos depreender como se estabelecem os conflitos.

A heterogeneidade dos sentidos atribuídos ao presidente durante sua campanha migrou para as duas mídias que analisamos, o que mostra que a polaridade analisada por Braga (2020) não se 
V. 11 (3) 356-385 set-dez 2021

restringiu ao período eleitoral, na busca por eleitores, mas se prolongou nos primeiros 30 dias de seu governo. Enquanto Veja desmistifica o presidente, os tweets significam o contrário, mas não são convincentes: mais do que ter, apenas parece que temos um presidente.

\section{Referências}

AGÊNCIA LUPA. \#Verificamos: Atentado contra Jair Bolsonaro com checagens em tempo real. Disponível em: https://piaui.folha.uol.com.br/ lupa/2018/09/06/atentado-bolsonaro-tempo-real/. Acesso em: 01 jul. 2021.

ASSIS, Machado de. Como se inventaram os almanaques. In: MEYER, Marlyse (Org.). Do almanak aos almanaques. São Paulo: Ateliê Editorial, 2001, p. 2528. Disponível em: http://bit.ly/3povrtM. Acesso em: 16 dez. 2020.

BAKHTIN, Mikhail (Volochinov). Marxismo e Filosofia da Linguagem. Tradução Michel Lahud e Yara Frateschi Vieira. 9. ed. São Paulo: Hucitec, 1999.

BAKHTIN, Mikhail. Problemas da poética de Dostoiévski. Tradução de Paulo Bezerra. 5. ed. Rio de Janeiro: Forense Universitária, 2010.

BAKHTIN, Mikhail. Teoria do romance I: o romance como gênero literário. São Paulo: Editora 34, 2015.

BRAGA, José Luiz. Polarização como estrutura da tolerância: uma questão comunicacional. In: Heller, Barbara et al. Midiatização e (in)tolerância. Salvador: Edufba, 2020.

DEBORD, Guy. A sociedade do espetáculo - comentários sobre a sociedade do espetáculo. Rio de Janeiro: Contraponto, 1997.

FÍGARO, Roseli; MOLIANI, José Augusto; MARQUES, Ana Flávia; KINOSHITA, Jamir. Jornalismo digital: questões metodológicas da análise das condições de produção nos novos arranjos do trabalho dos jornalistas. Anais. [S.l.]: [s.n.], 2020. Disponível em: http://www3.eca.usp.br/sites/default/files/form/ biblioteca/acervo/producao-academica/003023686.pdf

FIORIN, José Luiz. Introdução ao pensamento de Bakhtin. São Paulo: Ática, 2008.

FELDMAN, Sérgio Alberto. Da santificação do nome divino ao libelo de sangue: interações entre judeus e cristãos no período das cruzadas. Revista Graphos, v. 15, n. 1, 30 jun. 2013, p. 2-19. Disponível em: https://periodicos.ufpb.br/ ojs2/index.php/graphos/article/view/16320. Acesso em: 16 dez. 2020.

JOSEMIN, Gilberto Clovis. Entendimento interpretativo em pesquisa qualitativa sobre sistemas de informação. XXXV Encontro da Anpad. Disponível em: http://www.anpad.org.br/admin/pdf/ADI1539.pdf. Acesso em: 03 set. 2021.

MARTÍN-BARBERO, Jesús. Dos meios às mediações: comunicação, cultura e hegemonia. Prefácio de Néstor García Canclini. Tradução de Ronald Polito e Sérgio Alcides. Rio de Janeiro: UFRJ, 1997. 
MARCONDES FILHO, Ciro (Org). Dicionário da comunicação. 2. ed. São Paulo: Paulus, 2009.

MENDONÇA, Carolina Bittencourt. Escrevendo uma história: a experiência da Cia. de Canetas Compactor em Nova Iguaçu (1955-1995). 2014. 52 p. Trabalho de conclusão de curso (Licenciatura em História) - Instituto Multidisciplinar, Universidade Federal Rural do Rio de Janeiro, Nova Iguaçu, 2014. Disponível em: https://bit.ly/38fymZc. Acesso em: 20 nov. 2020.

RECUERO, Raquel da Cunha. Disputas discursivas, legitimação e desinformação: o caso Veja x Bolsonaro nas eleições de 2018. Comun. Mídia consumo, são paulo, v. 16, n. 47, p. 432-458, set./dez. 2019. Disponível em: $\quad$ https://www.researchgate.net/publication/337882190_Disputas discursivas_legitimacao_e_desinformacao_o_caso_Veja_x_B্Bolsonaro_nas_eleicoes_brasileiras_de_2018. Acesso em: 04 jul. 2021.

RIBAS, Mariana. Jânio de pé torto: símbolo de dias complicados. Aventuras na História. Uol. Publicado em: 31 jan. 2019. Disponível em: http://fpjq.org. br/2019/02/19/janio-de-pe-torto-simbolo-de-dias-complicados/. Acesso em: 16 dez. 2020.

SANTOS, Tarcyane dos. A comunicação nas teorias das mídias digitais no Brasil e nos Estados Unidos. Famecos. Porto Alegre, v. 23, n. 1, jan.-abr. 2016. Disponível em: https://revistaseletronicas.pucrs.br/ojs/index.php/ revistafamecos/article/view/21490. Acesso: 13 dez. 2020.

SILVA, Antônio de Morais; BLUTEAU Rafael. Diccionario da lingua portugueza composto pelo padre D. Rafael Bluteau, reformado, e accrescentado por Antonio de Moraes Silva natural do Rio de Janeiro. Lisboa, 1789.Disponivel em: https://digital.bbm.usp.br/handle/bbm/5412. Acesso em: 15 dez. 2020.

SUASSUNA, Ariano. Almanaque armorial brasileira. Folha de São Paulo, Ilustrada. São Paulo: 10 jul. 2000. Disponível em: https://www1.folha.uol. com.br/fsp/ilustrad/fq1007200026.htm. Acesso em: 16 dez. 2020.

TRÄSEL, Thomas; LISBOA, Silvia; VINCIPROVA, Giulia Reis. Pós-verdade e confiança no jornalismo. Brazilian Journalism Research. v. 15, n. 3, p. 452473, 2019.

THOMPSON, John Brookshire. A mídia e a modernidade: uma teoria social da mídia. Petrópolis: Ed. Vozes, 2011.

VEJA. São Paulo: Editora Abril, n. 1, 11 set. 1968.

VEJA. São Paulo: Editora Abril, ed. 2615, n. 1, jan. 2019a. Capa.

VEJA. São Paulo: Editora Abril, ed. 2616, n. 2, jan. 2019b. Capa.

VEJA. São Paulo: Editora Abril, ed. 2617, n. 3, jan. 2019c. Capa.

VEJA MIDIA KIT 2019. Disponível em: http://publiabril.abril.com.br/marcas/ veja. Acesso em: 28 set. 2019. 